\title{
Cytoprotective Activity of $p$-Terphenyl Polyketides and Flavuside $B$ from Marine-Derived Fungi against Oxidative Stress in Neuro-2a Cells
}

\author{
Ekaterina A. Yurchenko ${ }^{1, *(\mathbb{D})}$, Ekaterina S. Menchinskaya ${ }^{1}$, Evgeny A. Pislyagin ${ }^{1}\left(\mathbb{D}\right.$, Ekaterina A. Chingizova ${ }^{1}$, \\ Elena V. Girich ${ }^{2}$, Anton N. Yurchenko 2,*D, Dmitry L. Aminin 1,3 and Valery V. Mikhailov ${ }^{4}$
}

Citation: Yurchenko, E.A.; Menchinskaya, E.S.; Pislyagin, E.A. Chingizova, E.A.; Girich, E.V.; Yurchenko, A.N.; Aminin, D.L.; Mikhailov, V.V. Cytoprotective Activity of $p$-Terphenyl Polyketides and Flavuside B from MarineDerived Fungi against Oxidative Stress in Neuro-2a Cells. Molecules 2021, 26, 3618. https://doi.org/ $10.3390 /$ molecules 26123618

Academic Editor: Fengqing Yang

Received: 22 April 2021

Accepted: 9 June 2021

Published: 13 June 2021

Publisher's Note: MDPI stays neutral with regard to jurisdictional claims in published maps and institutional affiliations.

Copyright: (c) 2021 by the authors. Licensee MDPI, Basel, Switzerland. This article is an open access article distributed under the terms and conditions of the Creative Commons Attribution (CC BY) license (https:// creativecommons.org/licenses/by/ $4.0 /)$.
1 Laboratory of Bioassays and Mechanism of Action of Biologically Active Substances, G.B. Elyakov Pacific Institute of Bioorganic Chemistry, Prosp. 100 Let Vladivostoku 159, 690022 Vladivostok, Russia; ekaterinamenchinskaya@gmail.com (E.S.M.); pislyagin@hotmail.com (E.A.P.); martyyas@mail.ru (E.A.C.); daminin@piboc.dvo.ru (D.L.A.)

2 Laboratory of Chemistry of Microbial Metabolites, G.B. Elyakov Pacific Institute of Bioorganic Chemistry, Prosp. 100 Let Vladivostoku 159,690022 Vladivostok, Russia; ev.girich@piboc.dvo.ru

3 Department of Biomedical Science and Environmental Biology, Kaohsiung Medical University, No.100, Shin-Chuan 1st Road, Sanmin Dist., Kaohsiung City 80708, Taiwan

4 Laboratory of Microbiology, G.B. Elyakov Pacific Institute of Bioorganic Chemistry, Prosp. 100 Let Vladivostoku 159,690022 Vladivostok, Russia; mikhailov@piboc.dvo.ru

* Correspondence: eyurch@piboc.dvo.ru (E.A.Y.); yurchenkoan@piboc.dvo.ru (A.N.Y.); Tel.: +7-423-231-9932 (E.A.Y.)

Abstract: The influence of $p$-terphenyl polyketides 1-3 from Aspergillus candidus KMM 4676 and cerebroside flavuside B (4) from Penicillium islandicum (=Talaromyces islandicus) against the effect of neurotoxins, rotenone and paraquat, on Neuro-2a cell viability by MTT and LDH release assays and intracellular ROS level, as well as DPPH radical scavenging activity, was investigated. Pre-incubation with compounds significantly diminished the ROS level in rotenone- and paraquat-treated cells. It was shown that the investigated polyketides 1-3 significantly increased the viability of rotenone- and paraquat-treated cells in two of the used assays but they affected only the viability of paraquat-treated cells in the LDH release assay. Flavuside B statistically increased the viability of paraquat-treated cells in both MTT and LDH release assays, however, it increased the viability of rotenone-treated cells in the LDH release assay. Structure-activity relationships for $p$-terphenyl derivatives, as well as possible mechanisms of cytoprotective action of all studied compounds, were discussed.

Keywords: marine fungi; secondary metabolites; cytoprotection; reactive oxygen species; paraquat; rotenone

\section{Introduction}

Marine-derived fungi are a known source of antioxidants [1]. They produce secondary metabolites which can directly scavenge reactive oxygen species [2] as well as activate the Keap1/Nrf2/ARE antioxidant cellular machinery [3] and as a result upregulate antioxidant enzymes' expression [4]. Both these direct and indirect natural antioxidants from marinederived fungi protect the cells from oxidative stress (OS) induced damage.

Paraquat (methylviologen, $\mathrm{N}, \mathrm{N}$-dimethyl-4,4'-dipyridynium dichloride) is the second most common herbicide in the world after glyphosate. Despite the protective measures applied, cases of illness and death from the toxic effects of paraquat are not uncommon [5]. The isoflavonoid rotenone is widely used in agricultural production as a pesticide. For a long time, it was believed that rotenone is not toxic to humans, however, in detailed studies, exposure to rotenone caused various toxic effects [6,7].

Paraquat induces the formation of reactive oxygen species (ROS) in cells as well as endoplasmic reticulum stress, apoptosis, mitochondrial damage, and inflammation, as evidenced by the regulation of various protein/signaling pathways [8]. Rotenone acts as a 
mitochondrial complex I inhibitor which resulted in the hyperproduction of ROS. In both cases, ROS overestimation leads to oxidative stress damage to DNA, lipid, and protein structures and mitochondrial dysfunction, as well as the activation of signaling associated with apoptosis.

During a large-scale study of low molecular weight secondary metabolites of marine fungi, it was found that a number of compounds protect murine neuroblastoma Neuro2a cells against OS induced by 6-hydroxydopamine, paraquat, and/or rotenone [9-13]. As a part of this study, we investigated the influence of $p$-terphenyl polyketides 1-3 from Aspergillus candidus KMM 4676 [14,15] and cerebroside flavuside B (4) (Figure 1) from Penicillium islandicum (=Talaromyces islandicus) [16] against the effect of rotenone and paraquat on Neuro-2a cell viability and intracellular ROS level as well as DPPH radical scavenging activity. In this communication, we report the very first information available on these results.<smiles>COc1cc(-c2ccc(O)cc2)c(OC)c(O)c1-c1ccc(O)cc1</smiles>

$\mathbf{1}$ terphenyllin<smiles>COc1cc(-c2ccc(O)c(O)c2)c(OC)c(O)c1-c1ccc(O)cc1</smiles>

2 3"-hydroxyterphenyllin<smiles>COc1cc(-c2ccc(O)cc2)c(OC)c(O)c1-c1ccc(O)c(O)c1</smiles>

3 3'-hydroxyterphenyllin<smiles>CCCCCCCCCCCCCC/C=C/[C@@H](O)C(=O)N[C@H](COC(O)C1OC2CC(O)C(O)C(O)C1O2)[C@@H](O)/C=C/CCC/C=C(\C)CCCCCCCC</smiles>

4 flavuside B

Figure 1. Chemical structure of investigated compounds.

\section{Results}

Polyketides 1 and 3 scavenged only 33.1\% and 41.3\% of DPPH radicals at concentrations of $100 \mu \mathrm{M}$ and half-maximal effective concentrations $\left(\mathrm{EC}_{50}\right)$ were not calculated $(>100 \mu \mathrm{M})$. Compound 2 scavenged $64.6 \%$ of DPPH radicals at the same concentration and $\mathrm{EC}_{50}$ was calculated as $73.1 \pm 3.1 \mu \mathrm{M}$. Scavenging activity of these substances was comparable to that of a standard antioxidant, ascorbic acid. Flavuside B (4) did not show any statistically significant radical scavenging effect in the DPPH test (Table 1).

Table 1. DPPH radical scavenging activity of investigated compounds.

\begin{tabular}{|c|c|c|c|}
\hline Compound & $\begin{array}{l}\% \text { of Radical Scavenging at } \\
100 \mu \mathrm{M}\end{array}$ & Compound & $\begin{array}{c}\% \text { of Radical Scavenging at } \\
100 \mu \mathrm{M}\end{array}$ \\
\hline 1 & $33.1 \pm 0.9$ & 3 & $41.3 \pm 2.1$ \\
\hline 2 & $64.6 \pm 1.1$ & 4 & $10.3 \pm 5.9$ \\
\hline Ascorbic acid & $67.3 \pm 3.4$ & & \\
\hline
\end{tabular}

Terphenyllin (1) showed a weak cytotoxic activity and a half-maximum decrease in Neuro-2a cell viability at a concentration of $101.5 \pm 0.9 \mu \mathrm{M}$. Compounds 2 and $\mathbf{3}$, as well as flavuside B (4), did not show any cytotoxic effect on Neuro-2a cell viability at concentrations up to $100 \mu \mathrm{M}$. In further experiments, all compounds were used at a non-toxic concentration of $10 \mu \mathrm{M}$.

The influence of polyketides $\mathbf{1 - 3}$ on the viability and lactate dehydrogenase (LDH) release in rotenone and paraquat treated Neuro-2a cells is presented in Figure 2. 


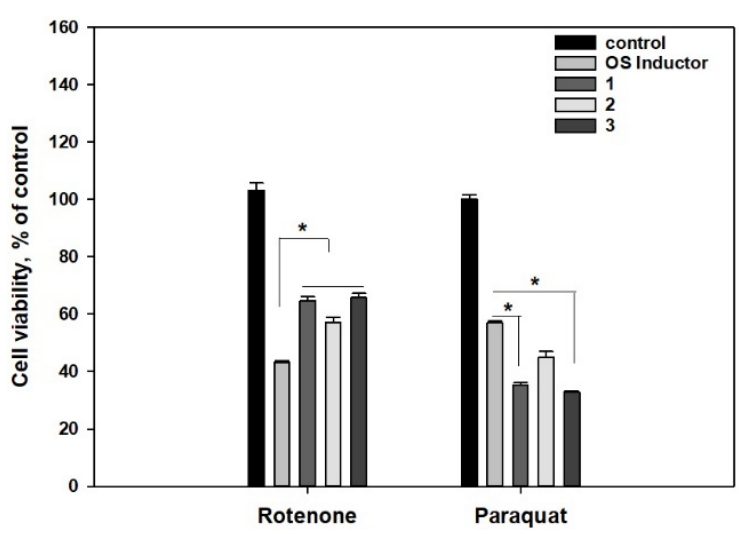

(a)

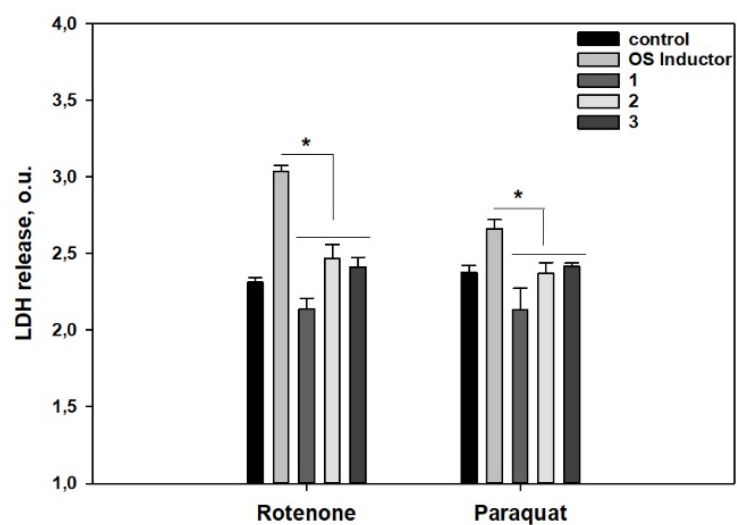

(b)

Figure 2. Influence of polyketides 1-3 on the viability estimated using MTT assay (a) and LDH release (b) in Neuro-2a cells treated with OS inductors, rotenone, and paraquat. Data are presented as mean \pm standard error mean (SEM). * indicates significant differences $(p \leq 0.05)$. Differences between control and rotenone or paraquat were significant.

Rotenone at a concentration of $10 \mu \mathrm{M}$ and paraquat at a concentration of $500 \mu \mathrm{M}$ reduced cell viability by $59 \%$ and $42 \%$ compared to the control, respectively. All investigated polyketides 1-3 significantly increased the viability of rotenone-treated cells by $49.6 \%, 32.0 \%$, and 52.3\%, respectively. At the same time, compounds 1 and 3 decreased the viability of paraquat-treated cells more than paraquat only (Figure 2a).

Rotenone and paraquat significantly increased the LDH release from Neuro-2a cells by $31.3 \%$ and $11.9 \%$, respectively. All investigated polyketides $1-3$ diminished the LDH release from rotenone-treated cells by $29.6 \%, 18.7 \%$, and $20.5 \%$, and paraquat-treated cells by $19.9 \%, 10.9 \%$, and $9.2 \%$, respectively (Figure $2 b$ ).

The influence of flavuside B (4) on the viability and LDH release in paraquat- or rotenone-treated Neuro-2a cells is presented in Figure 3.

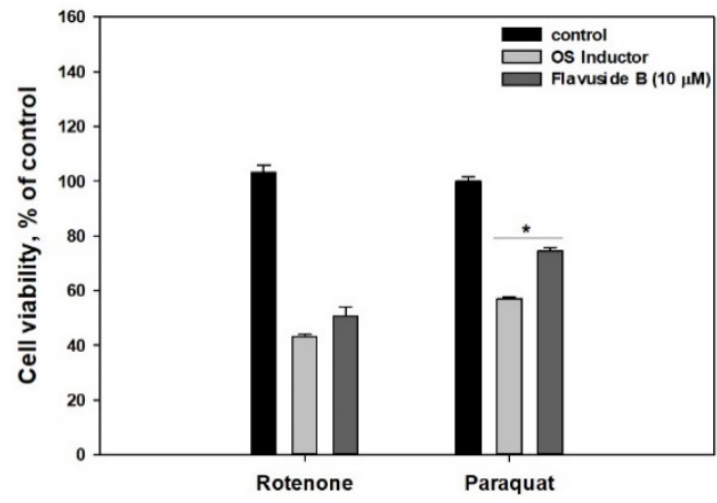

(a)

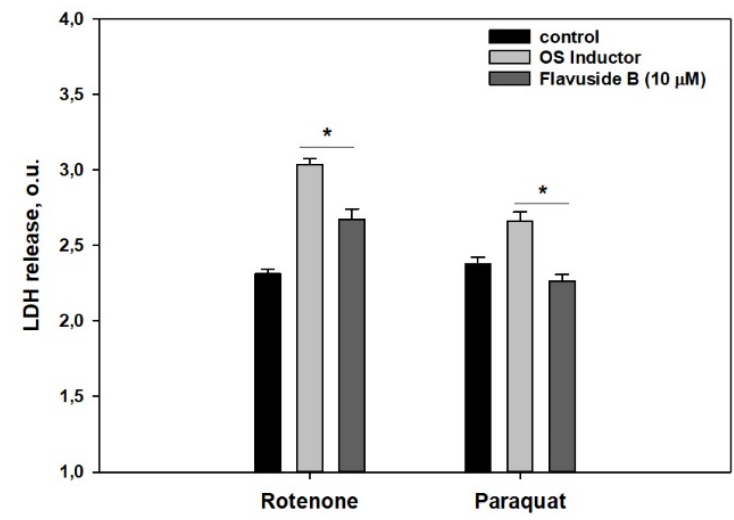

(b)

Figure 3. Influence of flavuside B (4) on the viability estimated using MTT assay (a) and LDH release (b) in Neuro-2a cells treated with OS inductors, rotenone, and paraquat. Data are presented as mean \pm SEM. * indicates significant differences $(p \leq 0.05)$. Differences between control and rotenone or paraquat were significant.

Flavuside B (4) increased the viability of paraquat-treated cells by $28.7 \%$ while its influence on rotenone-treated cell viability in the MTT test was not significant (Figure 3a). However, 4 significantly decreased LDH release both in rotenone- and paraquat-treated cells by $11.8 \%$ and $14.9 \%$, respectively (Figure $3 b$ ).

The ROS level in cells incubated with rotenone for $1 \mathrm{~h}$ almost doubled in comparison with untreated cells (Figure 4). The ROS level in cells incubated with paraquat for $1 \mathrm{~h}$, increased by $50 \%$ in comparison with untreated cells. Pre-incubation of cells with polyketides 1-3 significantly reduced ROS levels in rotenone- and paraquat-treated cells (Figure 4a). 


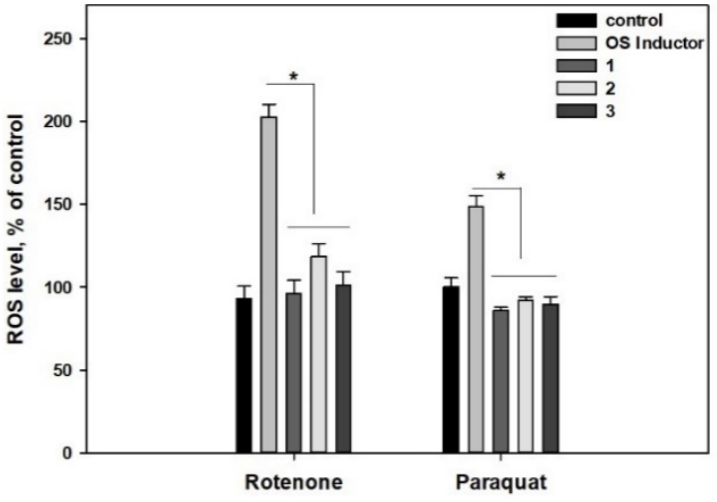

(a)

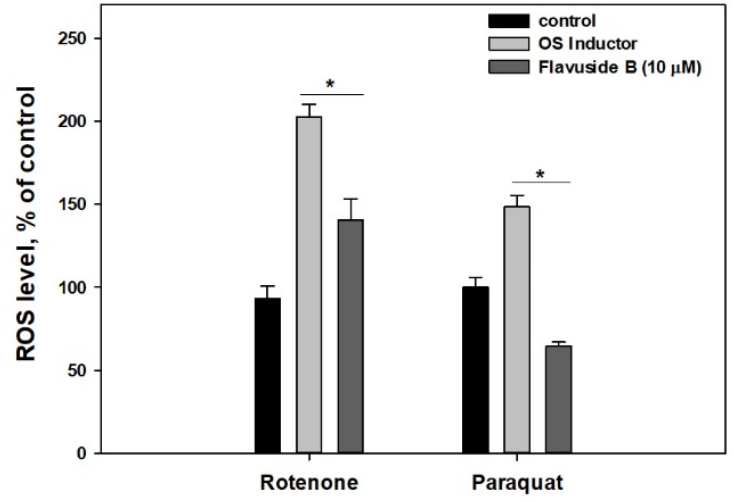

(b)

Figure 4. Influence of polyketides 1-3 (a) and flavuside B 4 (b) on ROS level in Neuro-2a cells treated with OS inductors, rotenone and paraquat. Data are presented as mean \pm standard error mean (SEM). * indicates significant differences $(p \leq 0.05)$. Differences between control and rotenone or paraquat were significant.

Pre-incubation of rotenone-treated cells with 4 caused a reduction in the ROS level of $30.7 \%$ compared to rotenone-treated cells. At the same time, pre-incubation of paraquattreated cells with flavuside B caused a significant diminishing of the ROS level by $56.8 \%$ compared to paraquat-treated cells (Figure $4 b$ ).

\section{Discussion}

Thus, terphenyllin (1) and their related compounds 3"-hydroxyterphenyllin (2) and $3^{\prime}$-hydroxyterphenyllin (3) showed significant anti-ROS activity in rotenone- and paraquattreated Neuro-2a cells. Moreover, the compounds 1-3 significantly decreased the LDH release from these cells although this is the opposite of the results obtained in the MTT test. The MTT assay is a widely exploited approach to investigate the effect of compounds on cell viability but MTT reduction can be significantly affected by metabolic and energy perturbations, changes in the activity of oxidoreductases, endo-/exocytosis, and intracellular trafficking [17]. For this reason, using an alternative assay for cell death/viability (LDH release or trypan blue staining) detection is necessary [18]. Terphenyl derivatives 1-3 increased MTT reduction in rotenone-treated cells but they impaired MTT reduction in paraquat-treated cells. This could lead to the conclusion that 1-3 together with paraquat are more toxic to Neuro-2a cells, however, the data on the LDH release contradicts this conclusion. Pre-incubation of Neuro-2a cells with compounds 1-3 significantly decreased the $\mathrm{LDH}$ release in paraquat-treated cells, and the LDH release values in cells treated with compounds 1-3 and paraquat were not statistically less than in control cells. Thus, it can be assumed that a significant decrease in MTT reduction was caused by the peculiarities of cellular metabolism, and the studied $p$-terphenyl polyketides 1-3 actually have cytoprotective properties against rotenone- and paraquat-induced OS.

The presence of an $\mathrm{OH}$ group at the $\mathrm{C}-3$ or C-3" position in their chemical structure did not significantly affect the cytoprotective activity of $p$-terphenyl polyketides. At the same time, as it was shown earlier by us, another $p$-terphenyl polyketide candidusin $\mathrm{A}$ which possessed an ether bond between C-2 and C-2' decreased the ROS level but did not affect cell viability in the MTT assay [13]. A free hydroxy group at C-2 in 3 instead of a bound hydroxy group in candidusin A allows for rotation around the C-1-C-1 ${ }^{\prime}$ bond and significantly changes the stereochemistry of the molecule. Earlier, it was published that the modification of $\mathrm{OH}$ groups at C-4 and C-4" as well as the presence of an OMe group at $\mathrm{C}-2^{\prime}$ in terphenyllin semi-synthetic derivatives resulted in a significant increase in the cytotoxicity of obtained compounds [19]. Probably, the presence of an $\mathrm{OH}$ group at the C-3 or C-3" position, as well as a free hydroxy group at C-2 in the chemical structures of 1-3, plays a key role in antioxidant and cytoprotective activities of $p$-terphenyl polyketides. 
Flavuside B (4) statistically increased the viability of paraquat-treated Neuro-2a cells in the MTT assay and reduced the LDH release in these cells while the cytoprotective effect of $\mathbf{4}$ on rotenone-treated cells was not so significant. The positive effect of 4 on rotenone-treated cell viability was not detected by the MTT assay, while 4 statistically decreased the LDH release in these cells. The anti-ROS effect of 4 was incredibly significant in paraquat-treated cells and less against rotenone-induced OS.

Obviously, differences between p-terphenyl polyketides (1-3) and flavuside B (4) activities are associated with the mechanism of the toxic action of paraquat and rotenone and, accordingly, the possible mechanism of the cytoprotective action of the compounds.

Rotenone is a direct inhibitor of mitochondrial complex I, also known as NADH: ubiquinone oxidoreductase (EC 7.1.1.2), which catalyzes the transfer of electrons from $\mathrm{NADH}$ to coenzyme Q10 and translocates protons across the inner mitochondrial membrane. Inhibition of mitochondrial complex I results in the overproduction of various ROS (peroxides and superoxides) that cause cell damage and death [20]. Paraquat causes the generation of intracellular free radicals via the reduction of the divalent paraquat ion $(\mathrm{PQ} 2+)$ to the monovalent paraquat ion $(\mathrm{PQ}+)$ by NADPH-oxidation of mitochondrial complex I and reestablishment of a new redox reaction by $\mathrm{PQ}+$, and induces OS in cells via the impairment of the redox cycling of glutathione and thioredoxin. Moreover, paraquat activates protein kinase delta, extracellular signal-regulated kinase $1 / 2$, Jun $\mathrm{N}$-terminal kinase, the caspase-3 signaling cascades, and other molecular signaling pathways [21].

Terphenyllin-related compounds have significant radical scavenging properties both in cell-free and cell-based assays and may act as direct antioxidants. In the case of rotenone, the direct antioxidant effect of $p$-terphenyls provides the scavenging of ROS and, as a result, increases cell viability measured in both MTT and LDH assays. At the same time, the direct antioxidant effect may not be enough to protect from paraquat toxicity, which causes more diverse toxic processes in cells, and cytoprotective influence was observed only in the LDH assay. However, this does not exclude the influence of 1-3 on antioxidant enzymes' activity, especially as both $\mathbf{2}$ and $\mathbf{3}$ earlier reduced ROS formation and increased catalase activity in human intestine INT-407 cells treated with $\mathrm{H}_{2} \mathrm{O}_{2}$ [22].

Flavuside $\mathrm{B}$ did not show a radical scavenging effect in the DPPH test and increase the viability of paraquat-treated cells, and the diminishing of the ROS level may be caused by the indirect antioxidant influence of flavuside B. This is supported by the fact that flavuside $B$ had no significant effect on the viability of rotenone-treated Neuro-2a cells.

Earlier flavuside B was founded only as an antimicrobial agent against Staphylococcus aureus and methicillin-resistant $S$. aureus [23]. Any cytoprotective activity of this cerebroside had not been reported, while other related cerebrosides showed anti-apoptotic and antiinflammatory activities. Thus, longan cerebroside II from rhizomes of Typhonium giganteum protected PC12 cells from glutamate injury by downregulating the expression of caspase9, caspase-3, and Bax, upregulating the expression of Bcl-2, and decreasing the level of cytosolic cytochrome c [24]. Cerebrosides from entomopathogenic fungus Cordyceps militaris inhibited the accumulation of pro-inflammatory iNOS protein and reduced the expression of COX-2 protein in LPS-stimulated RAW264.7 macrophages [25].

Thus, the cytoprotective effects of 1-4 on Neuro-2a cells treated with paraquat and rotenone were found, and the mechanism of their activity will be studied in detail in further research.

\section{Materials and Methods}

\subsection{Compounds}

The isolation of metabolites from marine fungi and their structural investigation have been reported previously [14,16]. Terphenyllin (1), 3"-hydroxyterphenyllin (2), and $3^{\prime}$-hydroxyterphenyllin (3) were isolated from ethyl acetate extract of the colonial ascidianassociated fungus Aspergillus candidus KMM 4676 (Shikotan Island, Northwest Pacific Ocean). Flavuside B was isolated from sediment-derived fungus Penicillium islandicum 
(depth $50 \mathrm{~m}$, Aniva Bay, Sea of Okhotsk). The ascidian and sediment samples were collected with Sigsbee trawl during expeditions aboard research vessel "Akademik Oparin."

The chemical structures of studied compounds are presented in Figure 1. Before the bioassays, all compounds were purified using earlier described HPLC procedures and their chemical purity was confirmed by HRESIMS $[14,16]$. All compounds were dissolved in DMSO $(100 \%)$ at a concentration of $10 \mathrm{mM}$. These solutions were used to obtain the required concentration of compounds in the cell suspension so that the concentration of DMSO in the cell suspension did not exceed $1 \%$.

\subsection{DPPH Radical Scavenging Assay}

The 2,2-diphenyl-1-picryl-hydrazyl-hydrate (DPPH) radical scavenging activity was tested as described previously [26]. The compounds were dissolved in $\mathrm{MeOH}$, and the solutions $(120 \mu \mathrm{L})$ were dispensed into wells of a 96-well microplate. The DPPH (SigmaAldrich, Germany) was dissolved in $\mathrm{MeOH}$ at a concentration of $7.5 \times 10^{-3} \mathrm{M}$ and the solution $(30 \mu \mathrm{L})$ was added to each well. The concentrations of tested compounds in the mixtures were 10 and $100 \mu \mathrm{M}$. Pure $\mathrm{MeOH}$ was used as a negative control and ascorbic acid was used as a positive control. The mixtures were shaken and left for $30 \mathrm{~min}$. The absorbance of the resulting solutions was measured at $\lambda=520 \mathrm{~nm}$ with a Multiscan FC plate reader (Thermo Scientific, Waltham, MA, USA). The results were presented as percent of the negative control $(\mathrm{MeOH})$ data.

\subsection{Neuro-2a Cell Culture}

The cells of the mouse neuroblastoma cell line Neuro-2a (ATCC ${ }^{\circledR}$ CCL-131 ${ }^{\mathrm{TM}}$; American Type Culture Collection, Manassas, VA, USA) were cultured in DMEM medium (Biolot, St. Petersburg, Russia) containing 10\% fetal bovine serum (Biolot, St. Petersburg, Russia) and $1 \%$ penicillin/streptomycin (Invitrogen, Carlsbad, CA, USA) at $37^{\circ} \mathrm{C}$ in a humidified atmosphere with $5 \%(v / v) \mathrm{CO}_{2}$. Initially, cells were incubated in cultural flasks until sub-confluent $(\sim 80 \%)$. For testing, Neuro-2a cells were seeded in 96-well plates and experiments were started after $24 \mathrm{~h}$.

\subsection{MTT Cell Viability Assay}

The cells $\left(1 \times 10^{4}\right.$ cells / well of a 96-well plate) were incubated with different concentrations of studied compounds for $24 \mathrm{~h}$. After that, cell viability was determined by the MTT (3-(4,5-dimethylthiazol-2-yl)-2,5-diphenyltetrazolium bromide) method according to the manufacturer's instructions (Sigma-Aldrich, St. Louis, MO, USA). The absorbance of the converted formazan was measured using a Multiskan FC microplate photometer (Thermo Scientific, USA) at $\lambda=570 \mathrm{~nm}$. The results were presented as a percentage of control data.

\subsection{Paraquat- and Rotenone-Induced Neurotoxicity}

The cells $\left(1 \times 10^{4}\right.$ cells / well of a 96-well plate) were treated with studied compounds at a concentration of $10 \mu \mathrm{M}$ for $1 \mathrm{~h}$. Then, $500 \mu \mathrm{M}$ of paraquat (Sigma-Aldrich, St. Louis, MO, USA) or $10 \mu \mathrm{M}$ of rotenone (Sigma-Aldrich, St. Louis, MO, USA) was added to the neuroblastoma cells and then incubated for $24 \mathrm{~h}$. The cells incubated without paraquat/rotenone and compounds and with paraquat/rotenone alone were used as positive and negative controls, respectively. The viability of cells was measured after $24 \mathrm{~h}$ using the MTT method. The results were presented as a percentage of positive control data.

\subsection{Lactate Dehydrogenase (LDH) Release Detection}

The cells $\left(1 \times 10^{4}\right.$ cells/well of a 96-well plate) were treated with studied compounds at a concentration of $10 \mu \mathrm{M}$ for $1 \mathrm{~h}$. Then, $500 \mu \mathrm{M}$ of paraquat (Sigma-Aldrich, St. Louis, MO, USA) or $10 \mu \mathrm{M}$ of rotenone (Sigma-Aldrich, St. Louis, MO, USA) was added to the neuroblastoma cells and the cells were incubated for $24 \mathrm{~h}$. The cells incubated without paraquat/rotenone and compounds and with paraquat/rotenone alone were used as 
positive and negative controls, respectively. Then, the plate was centrifuged at $250 \times g$ for $10 \mathrm{~min}$ and $100 \mu \mathrm{L}$ of supernatant from each well was transferred into the corresponding wells of an optically clear 96-well plate. An equal volume of the reaction mixture $(100 \mu \mathrm{L})$ from LDH Cytotoxicity Assay Kit (Abcam, Cambridge, UK) was added to each well and incubated for up to $30 \mathrm{~min}$ at room temperature. The absorbance (optical units, o.u.) of all samples was measured at $\lambda=490 \mathrm{~nm}$ using a Multiskan FC microplate photometer (Thermo Scientific, Waltham, MA, USA).

\subsection{Reactive Oxygen Species (ROS) Level Analysis}

The cells $\left(1 \times 10^{4}\right.$ cells/well of a 96-well plate) were incubated with compound solutions $(10 \mu \mathrm{M})$ for $1 \mathrm{~h}$. Then, paraquat $(500 \mu \mathrm{M})$ or rotenone $(10 \mu \mathrm{M})$ was added to the cell suspension to a resulting concentration for incubation for $1 \mathrm{~h}$. Cells incubated without paraquat/rotenone and compounds and with paraquat/rotenone alone were used as positive and negative controls, respectively. The $20 \mu \mathrm{L}$ of 2,7-dichlorodihydrofluorescein diacetate solution ( $\mathrm{H}_{2}$ DCFDA, Molecular Probes, Eugene, OR, USA) was added to each well $(10 \mu \mathrm{M}$, final concentration) and the plate was incubated for an additional $10 \mathrm{~min}$ at $37^{\circ} \mathrm{C}$. The intensity of dichlorofluorescin fluorescence was measured with a PHERAstar FS plate reader (BMG Labtech, Ortenberg, Germany) at $\lambda_{\mathrm{ex}}=485 \mathrm{~nm}$ and $\lambda_{\mathrm{em}}=518 \mathrm{~nm}$. The data were processed by MARS Data Analysis v. 3.01R2 (BMG Labtech, Ortenberg, Germany). The results were presented as a percentage of positive control data.

\subsection{Data Evaluation}

All data were obtained in three independent replicates and calculated values were expressed as mean \pm standard error mean (SEM). A Student's t-test was performed using SigmaPlot 14.0 (Systat Software Inc., San Jose, CA, USA) to determine statistical significance.

Author Contributions: Conceptualization, E.A.Y. and A.N.Y.; Methodology, E.A.Y., E.S.M., and E.A.P.; Validation, E.A.Y.; Investigation, E.A.Y., E.S.M., E.A.P., E.A.C., and E.V.G.; Writing-Original Draft Preparation, E.A.Y. and A.N.Y; Writing—Review and Editing, D.L.A. and V.V.M.; Visualization, E.A.Y. and A.N.Y.; Supervision, D.L.A.; Funding Acquisition, V.V.M. All authors have read and agreed to the published version of the manuscript.

Funding: This research was funded by a Grant of the Ministry of Science and Higher Education, Russian Federation 13.1902.21.0012 (contract No 075-15-2020-796).

Institutional Review Board Statement: Not applicable.

Informed Consent Statement: Not applicable.

Data Availability Statement: Not applicable.

Conflicts of Interest: The authors declare no conflict of interest.

Sample Availability: Samples of the compounds are not available from the authors.

\section{References}

1. Vitale, G.A.; Coppola, D.; Esposito, F.P.; Buonocore, C.; Ausuri, J.; Tortorella, E.; de Pascale, D. Antioxidant molecules from marine fungi: Methodologies and perspectives. Antioxidants 2020, 9, 1183. [CrossRef]

2. Leutou, A.S.; Yun, K.; Son, B.W. Induced production of 6,9-dibromoflavasperone, a new radical scavenging naphthopyranone in the marine-mudflat-derived fungus Aspergillus niger. Arch. Pharm. Res. 2016, 39, 806-810. [CrossRef]

3. Wu, Z.; Wang, Y.; Liu, D.; Proksch, P.; Yu, S.; Lin, W. Antioxidative phenolic compounds from a marine-derived fungus Aspergillus versicolor. Tetrahedron 2016, 72, 50-57. [CrossRef]

4. Kim, K.W.; Kim, H.J.; Sohn, J.H.; Yim, J.H.; Kim, Y.C.; Oh, H. Anti-neuroinflammatory effect of 6,8,1'-tri-O-methylaverantin, a metabolite from a marine-derived fungal strain Aspergillus sp., via upregulation of heme oxygenase-1 in lipopolysaccharideactivated microglia. Neurochem. Int. 2017, 113, 8-22. [CrossRef]

5. Shadnia, S.; Ebadollahi-Natanzi, A.; Ahmadzadeh, S.; Karami-Mohajeri, S.; Pourshojaei, Y.; Rahimi, H.R. Delayed death following paraquat poisoning: Three case reports and a literature review. Toxicol. Res. 2018, 7, 745-753. [CrossRef] [PubMed] 
6. Segura-Aguilar, J. Neurotoxins as Preclinical Models for Parkinson's Disease. Neurotoxicity Res. 2018, 34, 870-877. [CrossRef] [PubMed]

7. Zhan, C.; Liu, G.; Li, J.; Li, G.; Li, T.; Zhao, H.; Li, L.; Yang, W.; Bai, N.; Zheng, M.; et al. Rotenone and 3-bromopyruvate toxicity impacts electrical and structural cardiac remodeling in rats. Toxicol. Lett. 2020, 318, 57-64. [CrossRef] [PubMed]

8. Satpute, R.M.; Pawar, P.P.; Puttewar, S.; Sawale, S.D.; Ambhore, P.D. Effect of resveratrol and tetracycline on the subacute paraquat toxicity in mice. Hum. Exp. Toxicol. 2017, 36, 1303-1314. [CrossRef]

9. Zhuravleva, O.I.; Antonov, A.S.; Trang, V.T.D.; Pivkin, M.V.; Khudyakova, Y.V.; Denisenko, V.A.; Popov, R.S.; Kim, N.Y.; Yurchenko, E.A.; Gerasimenko, A.V.; et al. New Deoxyisoaustamide Derivatives from the Coral-Derived Fungus Penicillium dimorphosporum KMM 4689. Mar. Drugs 2021, 19, 32. [CrossRef]

10. Yurchenko, A.N.; Smetanina, O.F.; Ivanets, E.V.; Phan, T.T.H.; Ngo, N.T.D.; Zhuravleva, O.I.; Rasin, A.B.; Dyshlovoy, S.A.; Menchinskaya, E.S.; Pislyagin, E.A.; et al. Auroglaucin-related neuroprotective compounds from Vietnamese marine sedimentderived fungus Aspergillus niveoglaucus. Nat. Prod. Res. 2020, 34, 2589-2594. [CrossRef] [PubMed]

11. Smetanina, O.F.; Yurchenko, A.N.; Girich (Ivanets), E.V.; Trinh, P.T.H.; Antonov, A.S.; Dyshlovoy, S.A.; von Amsberg, G.; Kim, N.Y.; Chingizova, E.A.; Pislyagin, E.A.; et al. Biologically Active Echinulin-Related Indolediketopiperazines from the Marine Sediment-Derived Fungus Aspergillus niveoglaucus. Molecules 2020, 25, 61. [CrossRef] [PubMed]

12. Girich, E.V.; Yurchenko, A.N.; Smetanina, O.F.; Trinh, P.T.H.; Ngoc, N.T.D.; Pivkin, M.V.; Popov, R.S.; Pislyagin, E.A.; Menchinskaya, E.S.; Chingizova, E.A.; et al. Neuroprotective Metabolites from Vietnamese Marine Derived Fungi of Aspergillus and Penicillium Genera. Mar. Drugs 2020, 18, 608. [CrossRef] [PubMed]

13. Yurchenko, E.; Menchinskaya, E.; Pislyagin, E.; Trinh, P.; Ivanets, E.; Smetanina, O.; Yurchenko, A. Neuroprotective Activity of Some Marine Fungal Metabolites in the 6-Hydroxydopamin- and Paraquat-Induced Parkinson's Disease Models. Mar. Drugs 2018, 16, 457. [CrossRef] [PubMed]

14. Yurchenko, A.N.; Ivanets, E.V.; Smetanina, O.F.; Pivkin, M.V.; Dyshlovoi, S.A.; von Amsberg, G.; Afiyatullov, S.S. Metabolites of the Marine Fungus Aspergillus candidus KMM 4676 Associated with a Kuril Colonial Ascidian. Chem. Nat. Compd. 2017, 53, 747-749. [CrossRef]

15. Ivanets, E.V.; Yurchenko, A.N.; Smetanina, O.F.; Rasin, A.B.; Zhuravleva, O.I.; Pivkin, M.V.; Popov, R.S.; von Amsberg, G.; Afiyatullov, S.S.; Dyshlovoy, S.A. Asperindoles A-D and a p-terphenyl derivative from the ascidian-derived fungus Aspergillus sp. KMM 4676. Mar. Drugs 2018, 16, 232. [CrossRef]

16. Yurchenko, A.N.; Smetanina, O.F.; Ivanets, E.V.; Kirichuk, N.N.; Khudyakova, Y.V.; Yurchenko, E.A.; Afiyatullov, S.S. Metabolites from the Facultative Marine Fungus Penicillium islandicum. Chem. Nat. Compd. 2016, 52, 365-367. [CrossRef]

17. Stepanenko, A.A.; Dmitrenko, V.V. Pitfalls of the MTT assay: Direct and off-target effects of inhibitors can result in over/underestimation of cell viability. Gene 2015, 574, 193-203. [CrossRef]

18. Kepp, O.; Galluzzi, L.; Lipinski, M.; Yuan, J.; Kroemer, G. Cell death assays for drug discovery. Nat. Rev. Drug Discov. 2011, 10, 221-237. [CrossRef]

19. Zhang, X.Q.; Mou, X.F.; Mao, N.; Hao, J.J.; Liu, M.; Zheng, J.Y.; Wang, C.Y.; Gu, Y.C.; Shao, C.L. Design, semisynthesis, alphaglucosidase inhibitory, cytotoxic, and antibacterial activities of p-terphenyl derivatives. Eur. J. Med. Chem. 2018, 146, $232-244$. [CrossRef]

20. Chia, S.J.; Tan, E.-K.; Chao, Y.-X. Historical Perspective: Models of Parkinson's Disease. Int. J. Mol. Sci. 2020, 21, 2464. [CrossRef]

21. Bastias-Candia, S.; Zolezzi, J.M.; Inestrosa, N.C. Revisiting the Paraquat-Induced Sporadic Parkinson's Disease-Like Model. Mol. Neurobiol. 2019, 56, 1044-1055. [CrossRef]

22. Yen, G.C.; Chiang, H.C.; Wu, C.H.; Yeh, C.T. The protective effects of Aspergillus candidus metabolites against hydrogen peroxide-induced oxidative damage to Int 407 cells. Food Chem. Toxicol. 2003, 41, 1561-1567. [CrossRef]

23. Yang, G.; Sandjo, L.; Yun, K.; Leutou, A.S.; Kim, G.D.; Choi, H.D.; Kang, J.S.; Hong, J.; Son, B.W. Flavusides A and B, antibacterial cerebrosides from the marine-derived fungus Aspergillus flavus. Chem. Pharm. Bull. 2011, 59, 1174-1177. [CrossRef] [PubMed]

24. Jin, Y.; Fan, J.T.; Gu, X.L.; Zhang, L.Y.; Han, J.; Du, S.H.; Zhang, A.X. Neuroprotective Activity of Cerebrosides from Typhonium giganteum by Regulating Caspase-3 and Bax/Bcl-2 Signaling Pathways in PC12 Cells. J. Nat. Prod. 2017, 80, 1734-1741. [CrossRef] [PubMed]

25. Chiu, C.P.; Liu, S.C.; Tang, C.H.; Chan, Y.; El-Shazly, M.; Lee, C.L.; Du, Y.C.; Wu, T.Y.; Chang, F.R.; Wu, Y.C. Anti-inflammatory Cerebrosides from Cultivated Cordyceps militaris. J. Agric. Food Chem. 2016, 64, 1540-1548. [CrossRef] [PubMed]

26. Yurchenko, E.A.; Kolesnikova, S.A.; Lyakhova, E.G.; Menchinskaya, E.S.; Pislyagin, E.A.; Chingizova, E.A.; Aminin, D.L. Lanostane Triterpenoid Metabolites from a Penares sp. Marine Sponge Protect Neuro-2a Cells against Paraquat Neurotoxicity. Molecules 2020, 25, 5397. [CrossRef] [PubMed] 